Дубень Андрей Кириллович

Младший научный сотрудник

Институт государства и права Российской академии наук

\title{
ВЛИЯНИЕ ОБЩЕПРИЗНАННЫХ ПРИНЦИПОВ ПРАВА ПРИ ИНФОРМАЦИОННОЙ БЕЗОПАСНОСТИ ГОСУДАРСТВА
}

Аннотация: Выявление тенденций развития информационного права на базе современных технологий продемонстрировало роль и значимость общепризнанных принципов права при информационной безопасности государства. В статье освещаются проблемы места и значения принципов права в процессе обеспечения информационной безопасности. Автором проанализирован зарубежный опыт регулирования правоотношений в сфере информационного права, который позволил сделать вывод, что на сегодняшний день отсутствует доктринальная классификация базовых принципов в сфере информационной безопасности и соотношение общепризнанных принципов международного права между собой в аспекте их действия в области обеспечения информационной безопасности.

Ключевые слова: информаџионное право, информаџионная безопасность, принципь права, принцииь информационного права, правовое обеспечение информационной безопасности, ичифровизация права.

Keywords: information law, information security, principles of law, principles of information law, legal provision of information security, digitalization of law.

В условиях глобальной цифровой трансформации и необходимости построения информационного общества проблемы, касающиеся определения основополагающих принципов правового обеспечения информационной безопасности, приобретают особое значение. В связи с этим достаточно актуальным становится вопрос о научном осмыслении системы указанных принципов, их развитии и соотношении друг с другом, а также влиянии на информационные правоотношения.

Значение правовых принципов с точки зрения их роли в формировании правоприменительной практики и нормативно-правового материала является особенно 
высоким, в том числе в сфере обеспечения информационной безопасности. Правовые принципы служат ориентиром для законодателя, так как нормы, формулируемые им, не должны противоречить принципам права и в то же время должны представлять их детализированное выражение. Правовые принципы служат также ориентиром для правоприменителя, который при наличии неустранимых сомнений в толковании нормы права может выявить смысл нормы, обращаясь к общим принципам права. Кроме того, правоприменительный орган (в частности суд) может при наличии правового пробела, который не может быть устранен путем применения аналогии закона, применить аналогию права, основанную, как правило, на общих правовых принципах. Указанные аспекты имеют место и применительно к сфере обеспечения информационной безопасности.

Проблемы информационной безопасности, в связи с особенностями информационного пространства, могут носить трансграничный характер и затрагивать интересы сразу нескольких государств. Развитие информационно-коммуникационных технологий, способствующих формированию глобального информационного общества, позволяет нам говорить не только о принципах, действующих в рамках национального права, но и принципах, сформулированных в результате международно-правового взаимодействия государств [1].

Таким образом, базовыми, основополагающими принципами правового обеспечения информационной безопасности будут являться в первую очередь те нормативно установленные идеи, начала, положения, которые закреплены на международном уровне. В теории права также отмечается, что «общие принципы права наиболее полно отражаются в нормах международного права». Подобный вывод согласуется с ч. 4 ст. 15 Конституции Российской Федерации, согласно которой общепризнанные принципы и нормы международного права, и международные договоры Российской Федерации являются составной частью ее правовой системы [2].

В первую очередь стоит затронуть общепризнанные принципы международного права, имеющие общемировое значение. Источником закрепления указанных принципов является Устав ООН, Декларация о принципах международного права, касающихся дружественных отношений и сотрудничества между государствами в соответствии с Уставом ООН и Декларация тысячелетия ООН:

1) принцип неприменения силы и угрозы силой; 
2) принцип разрешения международных споров мирными средствами;

3) принцип невмешательства в дела, входящие во внутреннюю компетенцию государств;

4) принцип обязанности государств сотрудничать друг с другом;

5) принцип равноправия и самоопределения народов;

6) принцип суверенного равенства государств;

7) принцип, согласно которому государства добросовестно выполняют обязательства, принятые ими в соответствии с Уставом;

8) принцип нерушимости государственных границ;

9) принцип территориальной целостности государств;

10) принцип уважения прав человека и основных свобод [3].

Первые два из вышеназванных актов упоминают принцип, согласно которому государства разрешают свои международные споры мирными средствами таким образом, чтобы не подвергать угрозе международный мир, безопасность и справедливость. Информационное пространство абсолютным большинством современных стран определяется в качестве нового театра боевых действий. В связи с этим, стоит сделать вывод, что понятие международного мира и безопасности, упомянутое в рамках содержания указанного принципа, относится и к сфере международной информационной безопасности [4].

Окинавская хартия глобального информационного общества также закрепила ряд принципов, некоторые из которых имеют прямое отношение к области обеспечения информационной безопасности. Так, среди прочих принципов закрепляется: принцип дальнейшего развития и эффективного функционирования электронной идентификации, электронной подписи, криптографии и других средств обеспечения безопасности и достоверности операций; принцип развития эффективного и значимого механизма защиты частной жизни потребителя, а также защиты частной жизни при обработке личных данных, обеспечивая при этом свободный поток информации [5, с.53].

На формирование принципов правового обеспечения информационной безопасности повлияла также Декларация принципов, принятая в Женеве в 2003 году. В документе указывается на важность соблюдения принципа законности, который предполагает неукоснительное соблюдение национальных законов и норм, а также 
соответствующих международных соглашений. Одним из наиболее важных принципов, имеющих непосредственное отношение к сфере информационной безопасности, является принцип укрепления доверия и безопасности при использовании информационнотелекоммуникационных технологиях [6]. Из анализа Декларации следует, что данный принцип состоит из следующих элементов: 1) упрочение основы для доверия, включая информационную безопасность и безопасность сетей, аутентификацию, защиту неприкосновенности частной жизни и прав потребителей; 2) формирование, развитие и внедрение глобальной культуры кибербезопасности; 3) предотвращение использования информационных ресурсов и технологий в преступных и террористических целях.

Как можно заметить, общие начала, призванные обеспечить международную информационную безопасность, в настоящий момент уже можно считать сформированными. Однако нельзя сказать, что базовые принципы правового обеспечения информационной безопасности, закрепленные на международном уровне, представляют собой стройную систему. Попытка структурировать и придать системный вид базовым принципам обеспечения информационной безопасности была осуществлена Российской Федерацией, предложившей еще в 1999 году в рамках ООН «Принципы, касающиеся международной информационной безопасности». Однако предложенный документ с пятью базовыми принципами так и не был принят в качестве резолюции. С течением времени, в связи со стремительным развитием информационных технологий и формированием глобального информационного общества, неизбежно будет появляться потребность в формулировании новых принципов, пересмотр ранее закрепленных либо их иная интерпретация.

Принципы обеспечения информационной безопасности могут формулироваться не только на общемировом уровне, но и региональном. Определенное значение имеют принципы, закрепленные в результате интеграционного взаимодействия Российской Федерации с другими странами.

Таким образом, с течением времени, в связи с изменением политической и экономической обстановки в мире, вызванной глобализацией, интеграционное сотрудничество между государствами лишь возрастает, в том числе по вопросам международной информационной безопасности. Указанные проблемы были предметом рассмотрения на XIII Форуме по управлению Интернетом, проведенном в штаб-квартире ЮНЕСКО, на котором выступил Президент Франции с Парижским призывом к доверию и 
безопасности в киберпространстве. Однако среди более 50 стран, подписавших данный документ, России не оказалось. Думается, что связано это прежде всего с тем, что указанный документ носит декларативный характер, в связи с чем обязательность его исполнения юридически не подкреплена.

\section{Литература:}

1. Парижский призыв к доверию и безопасности в киберпространстве. URL: https://www.diplomatie.gouv.fr/IMG/pdf/appel_de_paris_en_russe_cle8a41ae.pdf (дата обращения: 08.12.2021).

2. Конституция Российской Федерации (принята всенародным голосованием 12 декабря 1993 г.) // Официальный интернет-портал правовой информации. URL: http://www.pravo.gov.ru, 01.07.2020.

3. Устав Организации Объединенных Наций (Принят в г. Сан-Франциско 26.06.1945) // Действующее международное право. Т. 1.- М.: Московский независимый институт международного права, 1996.

4. Международный пакт о гражданских и политических правах (Принят 16.12.1966 Резолюцией 2200 (XXI) на 1496-ом пленарном заседании Генеральной Ассамблеи ООН) // Бюллетень Верховного Суда РФ, № 12, 1994.

5. Окинавская хартия глобального информационного общества (Принята на о. Окинава 22.07.2000) // Дипломатический вестник. 2000. № 8. С. 51 - 56.

6. Женевская Декларация принципов «Построение информационного общества - глобальная задача в новом тысячелетии», принятая 12.12.2003 г. // Официальный сайт Организации Объединенных Наций. URL: https://www.un.org/ru/events/pastevents/pdf/dec_wsis.pdf (дата обращения: 08.12.2021). 